\title{
PARTISIPASI PUBLIK DALAM COLLABORATIVE GOVERNANCE PADA PROGRAM SISTER CITY BANDUNG DAN JEPANG DALAM MENANGGULANGISAMPAH DI KOTA BANDUNG
}

\author{
Thomas Bustomi $^{1)}$, Andre Ariesmansyah ${ }^{2}$ *), Asep Kusdiman ${ }^{3)}$ \\ ${ }^{1}$ Universitas Pasundan, Kota Bandung, Jawa Barat, Indonesia \\ thomas.bustomi@unpas.ac.id \\ ${ }^{2}$ Universitas Pasundan, Kota Bandung, Jawa Barat, Indonesia \\ andre.ariesmansyah@unpas.ac.id \\ ${ }^{3}$ Universitas Pasundan, Kota Bandung, Jawa Barat, Indonesia \\ asep.kusdiman@unpas.ac.id
}

\begin{abstract}
ABSTRAK
Partisipasi publik dalam proses pembuatan keputusan akan mendatangkan keuntungan, yakni memberikan kontribusi terhadap peningkatan kompetensi para pem- buat keputusan melalui pengembangan pembuatan kebijakan yang berkualitas, bahwa kondisi yang ada pada a wal kolaborasi dapat memfasilitasi atau menghambat kerja sama di antara para pemangku kepentingan dan antara lembaga dan pemangku kepentingan. sumber daya untuk berpartisipasi, atau untuk berpartisipasi secara setara dengan pemangku kepentingan lainnya, proses tata kelola kolaboratif akan rentan terha dap manipulasioleh aktoryang lebih kuat. Hasil observasi dan pengamatan di lapangan menunjukkan bahwa sampah yang berada di pasar tersebut belum dikelola dengan baik. Hal ini ditunjukkan daripenumpukan sampah dan daya tampung (TPS) yang kurang memadai di pasar sehingga sampah tercecer dimana-mana. Di sisi lain pola perilaku pengguna pasar yang belum dan cenderung tidak memiliki kesadaran untuk menjaga kebersihan besrama dan partisipasi dalam pengelolaan sampah masih kurang dan terabaikan, Karakteristik sampah di Kota Bandung terdiri dari sampah Organik (Sisa-sisamakanan, sayursayuran, buah-buahan) dan sampah Anorganik (plastik, alumunium, logam). Dari hasil penelitian dapat dikemukakan bahwa bahwa secara umum karakteristik sampah masih dominan sampah organik yang sebetulnya sangat mudah dioleh untuk kepentingan pembangunan lingkun gan; Faktor-faktor yang mempenga ruhi partisipasi public dalam pengelolaan sampah di Kota Bandung dengan model sister city menunjukan bahwa faktor internal (pendidikan, pendapatan, kepedulian terhadap sampah, pengetahuan tentang sampah) sementara pengetahuan tentang sampah pada aspek (Jenis sampah) tidak mempengaruhi tingkat partisipasi public, demikian juga faktor eksternalmeliputi (peraturan, bimbingan dan penyuluhan, dan fasilitas teknologi); Kondisi lingkungan (kondisi drainase) tidak mempengaruhi tingkat partisipasi public. Berjalan Ketika curah hujan tinggi dan banjiryang setiap tahun teralami. Memang perlunya meningkatkan sumber daya .
\end{abstract}

Kata Kunci: Partisipasi Publik, Collaborative, Sister City.

\footnotetext{
ABTRACT

Public participation in the decision-making process will bring us profit, which contributes to the improvement of the competence of the pem - made decisions through the development of policy-making quality, that the condition existing at the beginning of the collaboration can facilitate or inhibit cooperation among stakeholders and between institutions and stakeholders. resources to participate, or to participate on an equal basis with other stakeholders, the process of governance of the collaborative will be vulnerable to manipulation by actors that are more powerful. The results of the observation and field observations indicate that the trash that was in the market is not well managed. It is shown from the buildup of trash and carrying capacity (TPS) is inadequate in the market so that the rubbish scattered everywhere. On the other hand the behaviorpatterns of users of the market are not and tend to not have the awareness to maintain the cleanliness of the besrama and participation in waste management is still lacking and neglected, the Characteristics of the waste in the City of Bandung consists of
} 


\section{Kebijakan: Jurnal Ilmu Administrasi \\ Volume 13, Nomor 1, Januari 2022 \\ E-ISSN: 2656-2820 \\ P-ISSN 1829-5762}

Organic waste (Residual-sisamakanan, vegetables, fruits) and Inorganic waste (plastic, aluminum, metal). From the results of the research can be stated that in general the characteristics of the waste is still the dominant organic waste that are actually very easy by to the interests of the development environment; The factors that affect the participation of the public in waste management in the City of Bandung with model sister city showed that the internal factors (education, income, concern for the trash, knowledge about the garbage), while the knowledge about the garbage on the aspects (Type of waste) does not affect the level of participation of the public, thereby also external factors include (regulations, guidance and counseling, and technology facilities); environmental Conditions (drainage conditions) does not affect the level of participation of the public. Running When high rainfall and floods every year teralami. Indeed, the need to increase resources.

Keywords: Public Participation, Collaborative, Sister City.

\section{PENDAHULUAN}

Salah satu strategi membangun dan mewujudkan ketatapemeintahan yang baik (Good governance) adalah melibatkan dan mendorong partisipasipasi masyarakat dalam setiap aktivitas penyelenggaraan pemerintahan. Demokrasi sebagai inti dari Good Governance menuntut keikutsertaan seluruh elemen masyarakat dalam penyelenggaraan pemerintahan, dan pembangunan, mulai dari perumusan pembuatan dan penyusunan kebijakan sampai pada pelaksanaan dan pengendalian pemerintahan. Partisipasi publik dalam proses pembuatan kebijakan publik menurut Smith dan Ingram (1993) juga akan memberi manfaat bagi pemerintah. Sebab pemerintah akan menjadi lebih kuat dalam arti ada peningkatan kapasitas kelembagaan dalam pembuatan kebijakan yang akan berimplikasi pada peningkatan dukungan publik terhadap pemerintah, misalny a pemberian suara pemilihan umum. Ilmuan politik lainnya, Sample(1993), Webler, Kastenho,Z, dan Renn(1995) yang dikutipoleh Glicken(2000) mengatakan partisipasi publik dalam proses pembuatan keputusan akan mendatangkan keuntungan, yakni memberikan kontribusi terhadap peningkatan kompetensi para pem- buat keputusan melalui pengembangan pembuatan kebijakan yang berkualitas, mem- berikan legitimasi yang lebih besar terhadap keputusan-keputusan yang dibuat karena partisipasi publik dapat meningkatkan akun - tabilitas publik dalam proses pengambilan keputusan, serta memberikan citra positif sebagai suatu masyarakat demokratis.

Collaborative menggambarkan suatu hubungan kerja sama yang dilakukan pihak tertentu, Berdasarkan kamus Heritage Amerika (2000), Collaborative mampu bekerjabersamakhususnya dalam usaha penggabungan pemikiran Gray (1989) menggambarkan bahwa kolaborasi sebagai suatu proses berfikir dimana pihak yang terlibat memandang aspek-aspek perbedaan dari suatu masalah serta menemukan solusi dari perbedaan tersebut dan keterbatasan padangan mereka terhadap apa yang dapat dilakukan. Program sister city dalampenanganan sampah menghadirkan ketidakjelasan bagi masarakat, kondisi sampah di kota bandung sudah tidak terintegrasi dengan Undang-Undang Nomor 32 tahun 2009 tentang perlindungan dan pengelolaan lingkungan hidup yang dimana menurut aturan tersebut Perlindungan dan pengelolaan lingkungan hidup adalah upaya sistematis dan terpadu yang dilakukan untuk melestarikan fungsi lingkunganhidup dan mencegah terjadinya pencemaran dan/atau kerusakan lingkungan hidup yang meliputi perencanaan, pemanfaatan, pengendalian, pemeliharaan, pengawasan, dan penegakan hukum.

Dewasa ini masyarakat semakin sadar bahwa mereka memiliki hak untuk ikut serta dalam penyelenggaraan pemerintahan dan pembangunan, sehingga pemerintah seharusnya meresponsnya dengan baik dengan melibatkan mereka dalam berbagai aktivitas pemerintahan dan pembangunan, berkaitan dengan hal atas tersebut ingin mengetahui dan melakukan penelitian lebih lanjut terkait Bagaimana Partisipasi publik dalam collaborative governance pada program sister city dalam penanganan masalah sampah di Kota Bandung. 


\section{Kebijakan: Jurnal Ilmu Administrasi \\ Volume 13, Nomor 1, Januari 2022 \\ E-ISSN: 2656-2820 \\ P-ISSN 1829-5762}

\section{METODE}

Penelitian menggunakan desain penelitian studi literatur dengan pendekatan kualitatif. Subjek penelitian, yaitu Masyarakat di Kota Bandung. Instrumen Penelitian Instrumen atau alat pengumpulan data utama adalah tim peneliti sendiri. Data Diperoleh langsung dari berbagai informasi dari peneliti terdahulu dan informasi media yang berkaitan dengan penelitian di atas, selanjutnya melakukan wawancara melalui teleconference aplikasi zoom meeting untuk melakukan wawancara terstruktur, selanjutnya mengobservasi dengan menggunakan panca indera untuk memperoleh informasi yag berkaitan dengan sister city dalam menanggulangi sampah di kota bandung baik dal am hal Kerjasama, keterlibatan dari masing masing aktor, selanjutnya dokumentasi perolehan data data yang dapat membantu jalannya penelitian ini untuk melengkapi kebutuhan pengolahan data secara kualitatif.

\section{PEMBAHASAN}

Kerja Sama Daerah Dengan Pemerintah Daerah Di Luar Negeri (KSDPL), pada awalnya kerjasama Sister City adalah kerjasama antara Pemerintah Kota di satu negara dengan Pemerintah Kota di luar negeri Indonesia yang berorientasi pada upaya menumbuh kembangkan hubungan persahabatan dan saling pengertian antar bangsa - bangsa yang berbeda. Namun kini digeser ke arah bentuk kerjasama yang konkrit dan saling menguntungkan. Kerjasama Sister City dipandang sangat membantu bagi fungsi - fungsi Pemerintah dalam membina Pemerintah Daerah dan masyarakat untuk turut serta secara aktif dalam pembangunan. Kerjasama Sister City dengan mitranya di luar negeri diarahkanuntuk penyelenggaraan hubungan dan kerjasama yang bermanfaat dan saling menguntungkan. Kerjasama Sister City merupakan persetujuan kerjasama antara dua kota, daerah setingkat provinsi, negara bagian atau prefektur yang memiliki satu atau lebih kemiripan karakteristik dimana dua daerah tersebut terdapat pada dua negara yang berbeda. Kemiripan tersebut misalnya ada pada kemiripan budaya, latar belakang sejarah atau jika dilihat dari segi geografis kedua daerah sama-sama daerah pantai atau daerah kepulauan.

Konsep Sister City pertama kali digunakan di Benua Eropa, yaitu antara Kota Keighley, Yorkshire Barat, Inggris dengan Kota Poix Du Nord, Perancis pada tahun 1920. Pada perkembangannya, muncul pula istilah Twin City atau Kota Kembar. Istilah Twin City lebih sering digunakan di benua Eropa, sementara istilah Sister City lebih sering digunakan oleh Amerika Serikat. Selain Amerika Serikat, istilah Sister City juga digunakan di Indonesia. Hal ini mengacu pada surat edaran Menteri Dalam Negeri No. 193/1652/PUOD tanggal 26 April 1993 perihal Tata Cara Pembentukan Hubungan Kerjasama Antar Kota (Sister City) dan Antar Provinsi (Sister Province) dalam dan luar negeri. Di Indonesia sendiri konsep Sister City lebih ditujukan untuk pembangunan ekonomi, akan tetapi bidang - bidang seperti pendidikan dan budaya termasuk salah satu isu yang penting dalam skema Sister City. Pelaksanaannya, kerjasama Sister City harus berpedoman pada peraturan dan tertib administrasi sesuai Peraturan Menteri Dalam Negeri Nomor 3 Tahun 2008 tentang Pedoman Pelaksanaan Kerjasama Pemerintah Daerah dengan Pihak Luar Negeri. Perencanaan dan pelaksanaan kerjasama Pemerintah Daerah dengan pihak luar negeri juga harus sesuai dengan kemampuan daerah dalam hal keuangan, kelembagaan dan ketersediaan SDM aparatur serta sesuai dengan potensi dan kebijakan pihak mitra asing.

\section{Asal Muasal program sister city di Kota Bandung}

Sister City Kota Bandung atau kota bersaudara yang digunakan di Kota Bandung juga didasarkan kepada PERMENDAGRI Nomor I tahun 1992, yang menyebutkan bahwa kerjasama Sister 


\section{Kebijakan: Jurnal Ilmu Administrasi \\ Volume 13, Nomor 1, Januari 2022 \\ E-ISSN: 2656-2820 \\ P-ISSN 1829-5762}

City adalah hubungan kerjasama kota bersaudara yang dilaksanakan antara Pemerintah Kota, Pemerintah Kabupaten dan Pemerintah Kota Administratif dengan Pemerintah Kota setingkat di luar negeri. Pelaksanaan kerjasama Sister City di Kota Bandung mulai muncul pada tahun 1960, yaitu kerjasama Sister City yang terjalin dengan Kota Braunschweig, Jerman. Kerja sama ini merupakan salah satu bentuk kerjasama tertua di Indonesia. Seiring dengan perkembangannya, Kota Bandung juga menjalin kerjasama Sister City dengan beberapa kota lain.

Hubungan kerjasama yang terjalin antara Kota Bandung dengan kota - kota tersebut tentunya dimaksudkan untuk meningkatkan pembangunan ekonomi maupun pembangunan di bidang-bidang lainnya. Oleh karenanya, hubungan kerjasama harus dilengkapi dengan program kegiatan yang tetap dan terencana, baik mengenai bidang - bidang yang akan dikerjasamakan, tujuan yang ingin dicapai, konstruksi biaya masing-masing pihak, maupun mengenai lamanya waktu yang diperlukan bagi program kegiatan yang dikerjasamakan. Adapun beberapa bidang yang menjadi bidang kerjasama Sister City antara lain: 1). Ekonomi, Perdagangan, Investasi, Industri, dan Pariwisata 2) Ilmu Pengetahuan, Teknologi, dan Administrasi, 3) Pendidikan, Kebudayaan, Kesejahteraan Sosial, Pemuda dan Olahraga 4) Bidang-bidang lain yang kemudian akan disetujui oleh kedua belah pihak yaitu antara lain tentang persampahan.kerjasama dengan Jepang

Kawasaki merupakan Kota terpadat ke-9 di Jepang dan merupakan Kota satelit bagi Tokyo. Memajukan program-program yang ruang lingkup Kerjasama berhubungan dengan Alih teknologi lingkungan, pengembangan SDM dan Pertukaran informasi dan kerjasamaantar lembaga akademik dan penelitian untuk lingkup : 1) Manajemen limbah padat,2) Manajemen air limbah3) Manajemen kualitas udara 4) Manajemen energi 5) Teknologi transportasi dan 5) Bidang lingkungan hidup lainnya yg disepakati para pihak. Aktivitas yang sudah terimplementasikan Program waste management support toward a sustainable resource recycling society in Bandung.

\section{Gambaran Umum Partisipasi Publik Dalam Collaborative Governance Pada Program Sister City Bandung Dan Jepang Dalam Menanggulangi Sampah Di Kota Bandung}

Sudah sejak lama Pemerintah Kota Bandung menerapkan dan melaksanakan paradiplomatik Sister City dalam rangka kemajuan dan bermuara pada kesejatraan dan keindahan Kota Bandung. Terlebih semakin majunya teknologi digital menanggulangi permasalahan di Kota Bandung. Jumlah minat Kerjasama internasional ini disebakan dengan telah terjadinya trasnparansi Kerjasama antar negara yang semakin berkualitas dan menjurus pada persoalan yang sangat prinsip pada dataran pelayanan public. Kompetensi semakin menunjukan adanya Gerakan spesifikasi pada tingkat penangulangan-penanggulangan masalah secara mandiri juga melakukan collaborasi governance pada program-program Sister City untuk saling membantu dan saling tukar menukar pengalaman pada focus permasalahan yang dihadapi secara masing-masing.

Partisipasi public/masyarakatdalam penyelenggaraan penangulangan sampah di Kota Bandung sebagai kerjasama pemerintah atau tatakelola kolaboratif. Proyek-proyek yang menggunakan skema Sister City biasanya menggunakan metode pengadaan yang menggabungkan desain, pembangunan, keuangan, operasi, dan pemeliharaan infrastruktur secara holistic dan inovatif. Infrastruktur penanggulangan sampah yang diperoleh melalui Sister City dinilai menarik bagi pemerintah karena manfaat ekonomi yang telah disediakan sebelumnya, alokasi dan transfer risiko kepada investor adopsi Negara Jepang dan pembayaran biaya pengadaannya joint antar pemangku kepentingan. Opsi penangulangan dan pengadaan yang lebih disukai daripada opsi alternatif lainnya, walaupun masih dalam skala incidental (Percontohan). SkemaScemaSister City sangat penting dipertimbangkan dalam pengadaan infrastruktur sektor publik, dan dipandang efisien dan efektif dalam menjalankan proyek 


\section{Kebijakan: Jurnal Ilmu Administrasi Volume 13, Nomor 1, Januari 2022 E-ISSN: 2656-2820 P-ISSN 1829-5762}

pelayanan public secara spesifik. Tatakelola kolaboratif diambil dari beragam praktik dan penelitian, mensintesis dan memperluas seperangkat kerangka kerja konseptual, temuan pen elitian, dan pengetahuan berbasis praktik ke dalam kerangka kerja integratif untuk tatakelola kolaboratif Sister City penanggulangan persampaahan di Kota Bandung. Kerangka kerja Sister City penanggulangan persampaahan di Kota Bandung, menetapkan seperangkat dimensi yang mencakup kontekssistem yang lebih besar, rezim tata kelola kolaboratif, dan dinamika dan tindakan kolaboratif internal yang dapat menghasilkan dampak dan adaptasi di seluruh sistem. Kerangka kerja ini menyediakan peta konseptual yang luas untuk menempatkan dan mengeksplorasi komponen-komponen sistem tatakelola lintas batas yang berkisar dari kebijakan atau kerja sama antar pemerintah dan pemerintahan luar negeri berdasarkan program hingga kolaborasi regional berbasis tempat dengan pemangku kepentingan hingga terjadi kemitraan/kerjasama Kota Bandung dengan Jepang dalam konteks dan kontek persampahan Kerangka kerja Sister City penanggulangan persampaahan di Kota Bandung dengan Jepang mengintegrasikan pengetahuan tentang tindakan pengumpulan, pembelajaran sosial kolaboratif dan proses penyelesaian konflik, dan pengaturan kelembagaan untuk kolaborasi lintas batas antar ide, gagasan dan konsep. Disajikan sebagai kerangka kerja umum yang dapat diterapkan untuk analisis pada skala yang berbeda, di arena kebijakan yang berbeda, dan berbagai tingkat kompleksitas terfokus pada peanggulangan sampah di Kota Bandung.

Analisa dalam mengatasi permasalahan persampahan sudah di upayakan dengan collaborative governance, Pemerintah Kota Bandung selama ini telah melakukan kerjasaman dengan pemerintah Jepang. Namun terkendala di kewenangan di mana hirarki meningkatkan pengetahuan masyarakat, Menaingkatkan partisipasi masyarakat, meningkatkan ketertarikan, keterikatan dan dan ketarkiatan masyarakat, serta mempengaruhi masyarakat. Sangat dipengaruhi oleh aktivitas masyarakat pada kekuatan focus daya piker pada eksistensi negara, menciptakan presepsi postif, mengajak melibatkan isu-isu persampahan secara spesifik, pemperkuat hubungan kerajsama kearah kegiatan bersama mengunjugi tempat sampah bersama, dan investasi Bersama. Peran dan keberadaan pemerintah Kota Bandung dan pemerintah Jepangan dalam sister City penangulangan sampah, adalah peran setara yang berdampak pada eksistensi penangulangan sampah itu sendiri yang menggulirkan peran masayarak/public yang berkelanjutan. Penguatan peran dan fungsi masyarakat dalam peanggulangan sampah memang masih juga masih dipertanyakan. Hal ini bisa dilihat dari adanya sejumlah program penanggulangan sampah itu yang seyogianya diharapkan berhasil, faktanya menunjukkan hasil yang sebaliknya. Kondisi demikian salah satunya disebabkan oleh lemahnya partisipasi masyarakat dalam pembangunan yang berkelanjutan itu. Wacana partisipasi public sudah mengemuka sejak lama, namun sampai saat in i istilah partisipasi masih menjadi paradoks. Kebijakan sister city seolah hanya menjadi urusan pemegang kekuasaan. Partisipasi yang merupakan bagian dari esensi demokrasi belum mampu memberikan kedaulatan pada rakyat. Partisipasi masyarakat hanya seperti retorika indah yang didengungkan untuk menarik simpati rakyat namun faktanya akses menuju kesana tidaklah mudah.

Rendahnya tingkat partisipasi masyarakat dan sulitnya akses masyarakat untuk berpartisipasi dalam pembangunan merupakan kondisi yang ironis, mengingat partisipasi masyarakat merupakan unsur penting dalam pembangunan yang menunjang keberhasilan dari suatu program. Partisipasi masyarakat merupakan aspek yang penting dalam pembangunan masyarakat. Partisipasi merupakan salah satu dari tiga unsur pembangunan berorientasi masyarakat selain unsur keadilan dan unsur pemberdayaan. Urgensi dari tingakat kepentingan partisipasi masyarakat setidaknya dapat ditinjau dari 4 (empat) hal yakni 1) partisipasi merupakan suatu hak, yang harus diperhatikan dan dihormati, 2) partisipasi merupakan suatu aksi kelompok, 3) partisipasi merupakan suatu bagian penting dari proses administrasi pembangunan ditingkat opersional 4) partisipasi merupakan suatu indikator pembangunan 


\section{Kebijakan: Jurnal Ilmu Administrasi \\ Volume 13, Nomor 1, Januari 2022 \\ E-ISSN: 2656-2820 \\ P-ISSN 1829-5762}

masyarakat yang berkelanjutan. Partisipasi masyarakat merupakan faktor penentu serta sekaligus sebagai indikator keberhasilan pembangunan yang berkelanjutan. Seberapa kerasnya usaha pemerintah membangun sister city, jika tidak melibatkan serta menumbuhkan partisipasi masyarakat serta tidak didukung oleh masyarakat, maka tingkat keberhasilan pembangunan penanggulangan sampah dan keberlanjutan program pembangunan akan berbeda dengan kondisi jika masyarakat berpartisipasi secara sesungguhnya.

Degradasi terkait dengan keberadaan lingkungan masyarakat yang penduduknya padat dan berkembang pesat di Kota Bandung. Adanya sampah/limbah rumah tangga dan sampah/limbah industri yang tidak terolah dengan baik dan menumpuk di TPS (tempat pembeuangan sampah sementara) dan juga fenomena sampah langsung mengalir ke aliran sungai cikapundung dan anak-anak sungai, berhubungan denga perilaku masyarakat yang membuang sampah sembarangan dan tidak pedulinya pembagian sampah organic dan non organic menjadi sebuah kebiasaan dengan tidak memperdulikan pada akibat yang ditimbulkan, yaitu kerusakan dan pencemaran pada ekosistem di Kota Bandung. Program pemerintah pada penanggulangan sampah dengan model sister city dengan jepang hanya baru pada tingkat pilot projek dan belum mampu menyelesaikan permasalahan yang terjadi secara berkelanjutan. Program tersebut baru sebatas tahap penyuluhan dan sosialisasi agar masyarakat adanya teknologi tepat guna, yang tidak adaptip dengan kehidupan masyarakatnya secara berkelanjutan. Kemudian hanya dianggap sebagai angin lalu karena program tersebut hanya berbentuk himbauan dan pilot pojek dan bukan sebuah pola pendidikan untuk membentuk kesadaran masyarakat atas pemeliharaan lingkungan dari sector persampahan.

\section{Tahapan Kerjasama Sister City}

Kerjasama sister city pemerintah Kota Bandung dengan pemerintah Kota-kota negara lain yang sederajat dengan Kota Bandung menggunakan tahapan-tahapan yang dilakukan yakni:

a Penjajakan yakni dilakukan dengan saling tukar menukar potensi yang dimiliki daerah antara kedua pihak. Pertukaran ini dapat memanfaatkan kantor perwakilan negara asing di Indonesia atau kantor perwakilan Republik Indonesia di luar negeri.

b Penandatanganan LoI (Letter of Intent), yakni Apabila keinginan untuk bekerjasama mendapat sambutan positif dari masing - masing pihak, maka antara kedua belah dapat menandatangani Letter of Intent (LoI).

c Penyusunan Rencana Kerjasama, yakni setelah ditandatanganinya LoI, Pemerintah Kota segera menyusun Rencana Kerjasama atau Term of Reference dan Plan of Action yang menggambarkan maksud dan tujuan kerjasama serta manfaat yang diperoleh.

d Persetujuan DPRD, yakni Rencana Kerjasama, Plan of Action dan LoI yang sudah ditandatangani kedua pihak kemudian diajukan kepada DPRD Kota untuk mendapatkan persetujuan.

e Permintaan Fasilitasi Pemerintah, yakni Setelah adanya persetujuan DPRD Kota, Pemerintah Kota mengajukan surat kepada Menteri Dalam Negeri Republik Indonesia untuk mohon fasilitasi kerjasama. Surat Permohonan ini dijadikan syarat untuk menentukan pembahasan Draft MoU dengan melibatkan Kementerian Luar Negeri Republik Indonesia, Sekretariat Negara Republik Indonesia, Kementerian Dalam Negeri Republik Indonesia dan Kementerian/lembaga terkait lainnya.

f Penyusunan Draft MoU (Memorandum of Understanding), yakni MoU untuk kerjasama Sister City tergolong Perjanjian Internasional, sehingga penyusunannya dilakukan oleh Direktorat Jenderal Hukum dan Perjanjian Internasional Kementerian Luar Negeri Republik Indonesia sebagai ahli hukum internasional. Draft yang telah disusun Kementerian Luar Negeri Republik Indonesia 


\section{Kebijakan: Jurnal Ilmu Administrasi Volume 13, Nomor 1, Januari 2022 E-ISSN: 2656-2820 P-ISSN 1829-5762}

tersebut kemudian dibahas pada forum Interkem (antar kementerian) yang terdiri dari Kementerian Luar Negeri Republik Indonesia, Sekretariat Negara Republik Indonesia, Kementerian Dalam Negeri Republik Indonesia dan Kementerian/lembaga terkait lainnya. Forum Interkem kemudian membubuhkan paraf pada draft MoU yang telah dibahas. Draft MoU hasil rapat interkem disampaikan oleh Kementerian Dalam Negeri Republik Indonesia kepada Kementerian Luar Negeri Republik Indonesia untuk diteruskan kepada perwakilan RI di luar negeri untuk dikomunikasikan dengan calon Sister City untuk mendapatkan tanggapan.

g Penandatanganan MoU (Memorandum of Understanding), yakni Draft MoU yang telah mendapatkan persetujuan mitra kerjasama luar negeri, oleh Kementerian Luar Negeri Republik Indonesia kemudian disampaikan kepada Kementerian Dalam Negeri Republik Indonesia dan Pemerintah Kota yang bersangkutan untuk prosesusulan Surat Kuasa(Full Power). Pemerintah Kota selanjutnya mengajukan permohonan penerbitan Surat Kuasa (Full Power) kepada Menteri Luar Negeri melalui Menteri Dalam Negeri dengan melampirkan draft MoU yang telah diparaf. Sekretaris Jenderal Kementerian Dalam Negeri atas nama Menteri Dalam Negeri mengirim surat rekomendasi kepada Menteri Luar Negeri untuk penerbitan Surat Kuasa (Full Power) penandatanganan MoU kepada pejabat yang namanya tertera dalam Surat Kuasa (Full Power) sesuai tanggal yang telah ditetapkan.Setelah Surat Kuasa (Full Power) terbit pejabat Pemerintah Kota/Walikota yang atas namanya diterbitkan Surat Kuasa (Full Power) dapat melakukan penandatanganan MoU dengan pejabat Pemerintah Kota mitra kerjasama di luar negeri. Penandatangan dapat dilakukan di dalam atau di luar negeri. Naskah MoU yang sudah ditandatangani dikirim kepada Kem enterian Luar Negeri untuk disimpan sebagai Dokumen Negara. Kementerian Luar Negeri menerbitkan salinan resmi yang sah sebagai pegangan Pemerintah Kota dan Kementerian Dalam Negeri.

h Pelaksanaan Kerjasama, yaitu setelah MoU ditandatangani, maka dokumen kerjasama tersebut mengikat kedua belah pihak dan program - program yang disepakati dapat mulai dilaksanakan. Pemerintah Kota membentuk tim kerja sebagai pelaksana harian dari hasil kegiatan yang disepakati. Pemerintah Kota dapat mengalokasikan dana yang mungkin timbul dalam kerjasama tersebut melalui APBD dan sumber - sumber lain yang sah.

i Evaluasi Pelaksanaan Kerjasama, yaitu Kementerian Dalam Negeri dan Kementerian/lembaga lain terkait akan melakukan Monitoring dan Evaluasi secara berkala untuk mengetahui capaian dan hasil kerjasama sesuai Instrumen Monitoring dan Evaluasi yang disusun oleh Kementerian DalamNegeri.

j Pelaporan Pelaksanaan Kerjasama, yaitu Pemerintah Kota menyampaikan laporan kepada Kementerian Dalam Negeri tentang pelaksanaan program kerjasama tersebut sesuai format yang terdapat pada Instrumen Monitoring dan Evaluasi. Hasil evaluasi dapat dijadikan dasar untuk pertimbangan rencana kerjasama Sister City selanjutnya dengan mitra lain kota di luar negeri.

\section{Fisiografis Daerah Penelitian}

Secara administrative Kota Bandung terdiri dari 30 kecamatan, 151 kelurahan Hal ini berpengaruh atau mempengaruhi terhadap tingkat volume sampah setiap harinya. Memicu meningkatnya volume sampah yang dihasilkan oleh hunian dan aktivitas penduduk Kota Bandung yang memiliki luas wilayah $167,4 \mathrm{Km} 2$ yang juga berkaitan erat dengan data curah hujan secara khusus, yakni 30 Derajat maka data curah hujan yang digunakan mempengaruhi pada partisipasi public. Iklim agak basah (dingin) di wilayah Kota Bandung dan curah hujan sangat mempengaruhi jenisjenis sampah. Pada musim hujan sampah yang dihasilkan yaitu sampah basah yang sulit terurai dan menyebabkan banyak tumpukan sampah di pasar dan TPS-TPS. Sedangkan pada musim kemarau sampah yang dihasilkan adalah sampah kering, sehingga sampah mudah terbawa oleh angin yang 


\section{Kebijakan: Jurnal Ilmu Administrasi Volume 13, Nomor 1, Januari 2022 E-ISSN: 2656-2820 P-ISSN 1829-5762}

memicu berserakannya sampah di pasar tradisional dan TPS. Karakteristik Sampah di Pasar Kota Bandung menunjukkan bahwa secara umum berkarakteristik sampah sampah organik (56\%), yaitu sampah yang berasal dari sayur-sayuran, buah-buahandan sisa-sisa makanan. Sedangkan sampah anorganik juga cukup besar(.47\%) yang berasal dari plastik, kertas, alumunium danlain -lain. Kondisi tersebut dikarenakan bahan-bahan yang dipakai penduduk mempunyai tempat/perumahan yang baik dan perumahan kumuh.

Sampah yang menumpukdi TPS banyak sampahorganik(dapat diurai).Pada tingkat patisifasi public secarakeseluruhan meliputi tahap perencanaan, pelaksanaan dan pemeliharaan dari sampah terkategori sedang. Hal ini disebabkan para tokoh masyarakat sudah ikut berpartisipasi dengan menghadiri pertemuan dan memberikan gagasan untuk kebersihan lingkungan, akan tetapi dalam pelaksanaanya (Pengangkutan sampah ke TPA) masih dilakukan oleh petugas kebersihan,karena mereka mengaku sudah membayar retribusi sampah, sehingga mereka beranggapan bahwa masalah kebersihan lingkungan perumahan sudah mulai tertata sedsangkan tahapan lanjutnya merupakantanggung jawab pemerintah daerah dan petugas kebersihan. Tahap perencanaan secara umum tingkat partisipasi masyakat terkategori sedang dan terkategori rendah juga cukup besar karena jarangnya masyarakat menghadiri pertemuan dan memberikan gagasan untuk kegiatan kebersihan dan kurangnya kesadaran masyarakat dalam menjaga kebersihan lingkungan umum. Padatahap pelaksanaan terkategori tinggi dan terkategori sedang juga cukup besar, karena sebagian besar di perumahan sudah berinisiatif untuk menyediakan tempat sampah sementara sendiri untuk mempermudah dalam membuang sampah dan mengantisipasi berserakannya sampah yang di bawa oleh angin, diacak hewan dan atau pemulung.

Pada tahap pemeliharaan lingkungan tentang sampah secara umum tingkat partisipas public terkategori sedang dan terkategori tinggi juga cukup besar, karena jarang mengumpulkan sampah pada tempat pembuangan sementara (TPS) yang disediakan oleh pemerintah daerah dan kurangnya kepedulian untuk menegur orang lain ketika membuang sampah sembarangan. Kondisi tersebut mengindikasikan bahwa masyarakat belum sepenuhnya memahami dan menyadari bahwa masalah kebersihan lingkungan hidup bukan saja tanggung jawab pemerintah daerah dan petugas kebersihanakan tetapi merupakan tanggung jawab Bersama Hal ini memperkuat penelitian Hadi, (2006) yang menunjukkan bahwa tingkat partisipasi yang masih sedang disebabkan oleh pelayanan yang diberikan pemerintah melalui dinas kebersihan kurang memuaskan, terutama dalam penyediaan tempat sampah dan dominan memperhatikan lingkungan umum dan jalan-jalan utama. Peran aktif masyarakat menyediakan tempat sampah sementara sendiri di tempat rumah sendiri. Faktorfaktor yang mempengaruhi tingkat Partisipasi Publik dalam Pengelolaan Sampah Pasar bersifat manual dan tidak berteknologi tinggia. Faktor internal (pendidikan, pendapatan,kepedulian terhadap sampah, pengetahuan tentang sampah), sedangkan pengetahuan tentang sampah pada aspek (Jenis sampah) tidak memiliki korelasi terhadap tingkat partisipasi. Hal tersebut dikarenakan masyarakat dalm membuang sampahanorganik cenderung memiliki tingkat partisipasi sedang, bahkan dominan memiliki tingkat partisipasi rendah. Dengan kata lain membuang sampah organik dengan anorganik setiap harinya cenderung memiliki presentase yang tidak merata.

Adapun faktor eksternal meliputi (peraturan, bimbingan dan penyuluhan, dan fasilitas), sedangkan kondisi lingkungan (kondisi drainase) tidak memiliki korelasi terhadap tingkat partisipasi. Hal tersebut dikarenakan yang mengaku kondiisi drainase rusak ringan dominan memiliki tingkat partisipasi sedang, dan yang mengaku kondisi drainase baik dominan memiliki tingkat partisipasi rendah dan sedang. Kondisi drainase relative baik pada bangunan pemerintah, swasta dan perumahan elite. Sedangkan diperumhan kumuh tidak baik, sehingga beranggapan bahwa masalah kebersihan 
lingkungan yang luas merupakan tanggungjawab pemerintah, dan dinas-dinasnya yang terkait. Kondisi drainase yang baik maupun rusak ringan menunjukkan presentase tingkat partisipasi public yang tidak merata, dengan kata lain kondisi drainase menunujukkan suatu kecenderungan yang tidak merata. Dari pernyataan tersebut dapat ditarik kesimpulan bahwa kondisi drainase tidak ada korelasi terhadap tingkat partisipasi publik.

\section{Partisipasi \& Collaborative Governance}

Menurut Oostthuizen (1984) konsep peran serta masyarakat (Citizen Participation atau Public Participation) dalam pembangunan kota muncul pada akhir tahun 1950-an di Amerika, dan di Inggris berkembang mulai pertengahan tahun 1960-an. Tetapi di Inggris, secara formal diundangkan dan mempunyai kekuatan hukum, baru berlaku pada tahun 1968 sebagaimana tercantum di dalam Town and Country Planning Act. 1968. Di Australia, keinginan untuk pelibatan peran serta masyarakat dalam proses pembangunan mencapai puncaknya pada tahun 1970-an. Public participatin in planning development di Australia berlangsung setelah mereka (Negara Bagian New South Wales) misalnya, mengubah bentuk State Planning Authority yang ada diganti dengan State Planning and Environmental Commision (SPEC) yang baru. SPEC ini kemudian, menyusun kembali peraturan perundang-undangan dan prosedur perencanaan untuk lebih memberikan peluang bagi ikut sertanya masy arakat dalam proses pembangunan. Menunjukkan bahwa sedikitnya terdapat lima bentuk model yang dikenal sebagai peranserta (partisipasi) masyarakat dalam proses kehidupan dan penghidupan, yaitu Partisipasi sebagai penelitian pasar, Sampah merupakan masalah yang perlu diperhatikan khususnya di daerah perkotaan.Sampah merupakan permasalahan lingkungan karena mengabaikan prinsip prinsip pengelolaan sumber daya alam dan lingkungan yang berkelanjutan, sehingga sampai saat ini banyak tempat dimuka bumi yang kondisi lingkungannya sangat buruk dan sebagian besar dalam kondisi kritis,(Ejasta, 2010:4).

Sampah perkotaan yang bersumber dari pasar tradisional dan pasar modern merupakan permasalahan perkotaan di indonesia. Dari tahun ketahun volume sampah semakin meningkat.Peningkatan volume sampah bukan hanya karena meningkatnya jumlahpedagang dan pembelisemata, tetapi juga disebabkan oleh meningkatnyakonsumsi dan perilaku pedagang di pasar tradisional. Budihardjo (2003:5) mengemukakan bahwa sampah merupakan masalah besar perkotaan, baik di negara berkembang maupun di negara maju. Masalah sampah di kota diantaranya mencakup semakin sulitnya memperoleh lahan baru untuk dijadikan tempat pembuangan sampah. Selain itu masalah sampah juga mencakup proses pengolahan dan pembuangan sampah, penipisan sumber dalam akibat pembuangan, serta pengolahan sampah yang memakan biaya besar. Pengelolaan sampah diatur dalam(Undang-Undang Nomor 18 Tahun 2008 Tentang Pengelolaan Sampah). Berdasarkan Pasal 1 angka 11 Undang-Undang Nomor 18 Tahun2008, yang dimaksud dengan pengelolaan sampah adalah kegiatan yang sistematis, menyeluruh, dan berkesinambungan yang meliputi pengurangan dan penanganan sampah. Pengurangan yang dimaksud adalah pemanfaatan kembali sampah, pendaur ulang sampah. Sementara penanganan sampah yang dimaksud meliputi pemilahan sampah, pengumpulan, pengangkutan, pengolahan, dan pemrosesan. Permasalahan sampah timbul disebabkan oleh beberapa faktor, yaitu pertumbuhan penduduk, pertumbuhan ekonomi, kesejahteraan penduduk, pola konsumsi masyarakat, perilaku penduduk, aktifitas fungsi kota, dan kepadatan penduduk (Profil Kota Kota Bandung Tahun2021). Permasalahan sampah pada pasar tradisional di kota Bandung tidak hanya berkaitandengan sulitnya memperoleh lahan sebagai tempat pembuangan akhir (TPA), akan tetapi partisipasi pedagang dalam pengelolaan sampah di pasar tradisional sangat kurang, Dampak kumuhnya lingkungan pasar suatu 


\section{Kebijakan: Jurnal Ilmu Administrasi Volume 13, Nomor 1, Januari 2022 \\ E-ISSN: 2656-2820 \\ P-ISSN 1829-5762}

bukti partisipasi di lingkungan pasar tidak terbentuk dengan baik. Perilaku buang sampah di pergerakan pasar sangat berpengaruh terhadap meningkatnya volume sampah di pasar tradisional. Penanganan masalah sampah di pasar tradisional sangat dibutuhkan adanya partisipasi dari pedagang, pengunjung dan gerakan bongkar muat transaksi jual beli yang tersistematis.

Partisipasi dan kesadaran pedagang dan para kepentingan terkait dengan pasar sangat dibutuhkan dalam menanggulangi masalah sampah pasar, karena masalah kebersihan lingkungan pasar bukan saja tanggung jawab dan kewajiban pemerintah daerah, tetapi juga menjadi tugas dan kewajiban integritid pada manajemen pasar pada umumnya. Partisipasi integritis di pasar sangat dibutuhkan dalam pelaksanaan pengumpulan dan pengangkutan sampah dari tempat pasar samapi ke TPA diperlukan mekanisme bantuan teknologi. Pendekatan partisipasi dengan kesadaran sendiri individu dan tersistem pada pola induk aturan yang di buat di pasar tradiosional dapat dikembangkan dengan sanksi yang tegas. Menjaga kebersihan lingkungan pasar.Pasar-pasar tradisional di kota Bandung telah dilengkapi dengan tempat pembuangan sampah sementara (TPS) atau bak sampah sebelum di angkut ke tempat pembuangan akhir(TPA) oleh petugas kebersihan. Namun, adanya tempat sampah tersebut cenderung tidakdimanfaatkan dengan baik oleh para terkait dengan kehidupandipasartradisional. Hasil observasi dan pengamatan di lapangan menunjukkanbahwa sampah yang berada di pasartersebut belum dikelola dengan baik. Hal ini ditunjukkan dari penumpukan sampah dan daya tampung (TPS) yang kurang memadai di pasar sehingga sampah tercecer dimanamana. Di sisi lain pola perilaku pengguna pasar yang belum dan cenderung tidak memiliki kesadaran untuk menjaga kebersihan besramadan partisipasi dalam pengelolaan sampah masih kurang dan terabaikan. Hal ini menyebabkan pasar menjadi tempat yang kotor, bau dan kumuh.

Aspek pengawasan dan sanksi yang tidak tegas, selain minimnya penyuluhan dari pihak pengelola pasar (KOPAS dan atau Dinas Pasar) mengenai sistem pengelolaan sampah yang baik serta dampak sampah terhadap kesehatan dan lingkungan. Permasalahan sampah yang dihadapi oleh pasar tradisional di Kota Bandung, tentumembutuhkan solusi. Berkenaan dengan itu, sebagai langkah awal penting untuk dikaji lebih jauh tentang permasalahan sampah tersebut dalam suatu penelitian yang mengurai detail dan melibatkan patisipasi keberlanjutan. Penelitian ini menarikkarena mengkaji permasalahan sampah di perkotaan khususnya di pasar tradisional kota Bandung yang selama ini menjadi momok bagi masyarakat sehingga berdampak pada kumuhnya lingkungan pasar. Karakteristik sampah di pasartradisional kota Bandung, secaraumum adalahbentuk dan wujudnya dominan sejenis organic maka tingkat partisipasi dalam pengelolaan sampah pasar tradisional di kota Bandung faktor faktor yang mempengaruhi pedagang dalam pengelolaan sampah pasar tradisional di kota Bandung berhubungan dengan kekotoran dan jijik, partisipasi sebagai pembuatan/pengambilan keputusan, partisipasi sebagai pemecah oposisi yang terorganisir, partisipasi sebagai sosial theraphy, dan partisipasi sebagai grass root radicalism. 
Collaborative Governance yang di sampaikan ansell and gash melalui pendekatan kelembagaan dapat di sampaikan pada gambar model di bawah ini.

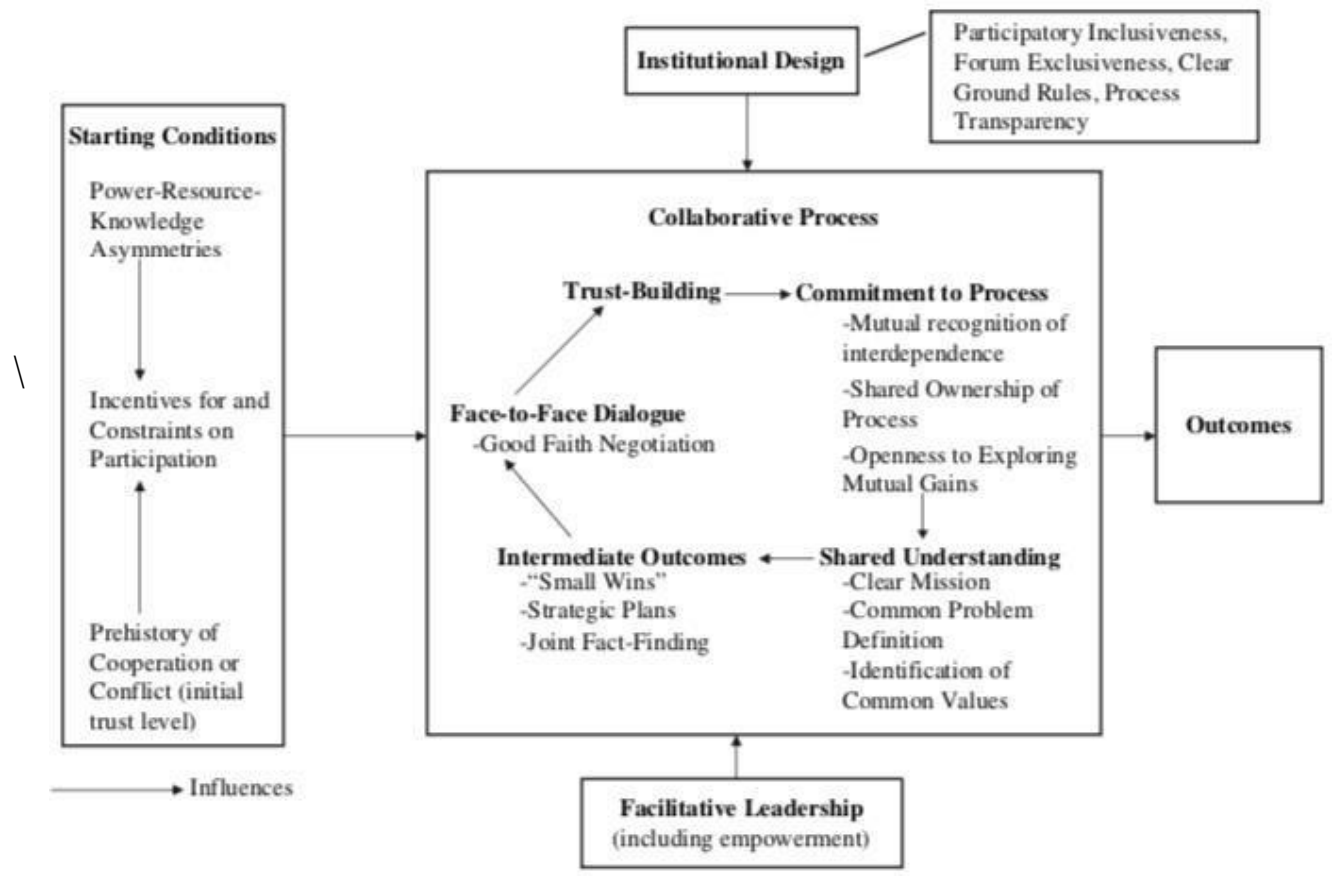

Gambar 1. Model Collaborative Governance

Literaturnya jelas bahwa kondisi yang ada pada awal kolaborasi dapat memfasilitasi atau menghambat kerja sama di antara para pemangku kepentingan dan antara lembaga dan pemangku kepentingan. Bayangkan dua titik awal yang sangat berbeda. Dalam satu, para pemangku kepentingan.memiliki sejarah pembagian pahit atas beberapa masalah lokal yang dibebankan secara emosional dan telah menganggap satu sama lain sebagai musuh yang tidak bermoral. Masalah ketidakseimbangan kekuasaan terutama bermasalah di mana pemangku kepentingan penting tidak memiliki inf rastruktur organisasi untuk diwakili dalam proses tata kelola kolaboratif. English (2000), misalnya, berargumen bahwa semakin terdifusi pemangku kepentingan yang terkena dampak, dan semakin lama cakrawala masalah, semakin sulit untuk mewakili pemangku kepentingan dalam proses kolaboratif. Dalam banyak kasus, masalahnya adalah bahwa kelompok pemangku kepentingan yang terorganisir tidak ada untuk mewakili pemangku kepentingan individu secara kolektif (Buanes et al. 2004; Rogers et al. 1993). Masalah umum lainnya adalah bahwa beberapa pemangku kepentingan mungkin tidak memiliki keterampilan dan keahlian untuk terlibat dalam diskusi tentang masalah yang sangat teknis (Gunton dan Day 2003; Lasker dan Weiss 2003; Merkhofer, Conway, dan Anderson 1997; Murdock, Wiessner, dan Sexton 2005; Warner 2006). Masalah umum ketiga adalah bahwa beberapa pemangku kepentingan tidak memiliki waktu, energi, atau kebebasan untuk terlibat dalam proses kolaboratif yang intensif waktu (Yaffee dan Wondolleck 2003). Tak satu pun dari masalah ini yang tidak dapat diatasi. Para pendukung kolaborasi telah menunjuk serangkaian strategi yang dapat digunakan untuk memberdayakan kelompok yang lebih lemah atau kurang terwakili (Fawcett et al. 1995; Lasker dan Weiss 2003; Merkhofer, Conway, dan Anderson 1997; Mitchell 2005; Schuckman 2001) 


\section{Kebijakan: Jurnal Ilmu Administrasi \\ Volume 13, Nomor 1, Januari 2022 \\ E-ISSN: 2656-2820 \\ P-ISSN 1829-5762}

\section{Incentives to Participate}

Insentif untuk berpartisipasi sebagian bergantung pada harapan pemangku kepentingan tentang apakah proses kolaboratif akan menghasilkan hasil yang bermakna, terutama terhadap keseimbangan waktu dan energi yang dibutuhkan kolaborasi (Bradford 1998; Geoghegan dan Renard 2002; Rogers dkk. 1993; Schneider dkk. 2003 ; Warner 2006). Insentif meningkat ketika pemangk u kepentingan melihat hubungan langsung antara partisipasi mereka dan hasil kebijakan yang konkret, nyata, dan ef ektif (Brown 2002). Tetapi mereka menolak jika pemangku kepentingan menganggap input mereka sendiri hanya sebagai penasehat atau sebagian besar seremonial (Futrell 2003)

\section{Prehistory of Antagonism or Cooperation}

Literatur menunjukkan bahwa prasejarah antagonisme atau kerja sama antara pemangku kepentingan akan menghambat atau memfasilitasi kolaborasi (Andranovich)

\section{Power/Resource Imbalances}

Ketidakseimbangan kekuasaan antara para pemangku kepentingan adalah masalah yang sering dicatat dalam tata kelola kolaboratif (Gray 1989; Short and Winter 1999; Susskind dan Cruikshank 1987; Tett, Crowther, dan O'Hara 2003; Warner 2006). Jika be berapa pemangku kepentingan tidak memiliki kapasitas, organisasi, status, atau 1995; Gray 1989; bnd. Margerum 2002). Namun, kami mencatat bahwa ketika para pemangku kepentingan sangat saling bergantung, tingkat konflik yang tinggi sebenarnya dapat menciptakan insentif yang kuat untuk pemerintahan kolaboratif. Dalam sejumlah kasus, kebuntuan kebijakan sebenarnya dapat menciptakan dorongan kuat untuk tata kelola kolaboratif (Futrell 2003). Weber menggambarkan asal usul kolaboratif lokal sebagai berikut: "Lelah dan frustrasi karena terus-menerus memperebutkan disposisi sumber daya alam dan pendekatan pengelolaan lahan, Brown dan Swenson (para pemimpin dari dua kelompok saingan) memutuskan untuk duduk dan melihat apakah ada alternatif, metode yang lebih bersahabat untuk mendamaikan perbedaan mereka" (Weber 2003, 59).

\section{Facilitative Leadership}

Kepemimpinan secara luas dilihat sebagai unsur penting dalam membawa pihak ke meja dan untuk mengarahkan mereka melalui tambalan kasar proses kolaborasi (Burger et al. 2001; Chrislip dan Larson 1994; Frame, Gunton, dan Day 2004; Gilliam et al. 2002; Gunton dan Hari 2003; Heikkila dan Gerlak 2005; Huxham dan Vangen 2000; Imperial 2005; Lasker dan Weiss 2003; Margerum 2002; Murdock, Wiessner, dan Sexton 2005; Reilly 1998, 2001; Roussos dan Fawcett 2000; Saarikoski 2000; Smit h 1998; Vangen dan Huxham 2003a).Meskipun negosiasi " tanpa bantuan " kadang-kadang mungkin, literatur secara berlebihan menemukan bahwa kepemimpinan fasilitatif penting untuk menyatukan para pemangku kepentingan dan membuat mereka saling terlibat dalam semangat kolaboratif (Chrislip dan Larson, 1994; Ozawa, 1993; Pine, Warsh, dan Maluccio 1998; Reilly 2001; Susskind dan Cruikshank 1987).

Menggambarkan tiga bentuk 'negosiasi yang dibantu,' Susskind dan Cruikshank (1987) menyarankan teknik mediasi yang semakin intervensionis sejauh para pemangku kepentingan tidak dapat berkolaborasi secara langsung. Vangen dan Huxham (2003) berpendapat bahwa untuk memajukan kolaborasi, para pemimpin harus sering mengintervensi dengan cara yang lebih terarah untuk membentuk agenda Kepemimpinan sangat penting untuk menetapkan dan mempertahankan aturan dasar yang jelas, membangun kepercayaan, memfasilitasi dialog, dan mengeksplorasi keuntungan bersama. Vangen dan Huxham (2003) berpendapat bahwa kepemimpinan penting untuk 


\section{Kebijakan: Jurnal Ilmu Administrasi \\ Volume 13, Nomor 1, Januari 2022 \\ E-ISSN: 2656-2820 \\ P-ISSN 1829-5762}

merangkul, memberdayakan, dan melibatkan para pemangku kepentingan dan kemudian memobilisasi mereka untuk memajukan kolaborasi. Chrislip dan Larson $(1994,125)$ menggambarkan pemimpin kolaboratif sebagai pelayan dari proses (mentransformasikan, melayani, atau kepemimpinan fasilitatif) yang gaya kepemimpinannya adalah “ . . . ditandai dengan fokusnya pada promosi dan pengamanan proses (bukan pada pemimpin individu yang mengambil tindakan tegas). Lasker dan Weiss (2001, 31) berpendapat bahwa pemimpin kolaboratif harus memiliki keterampilan untuk mempromosikan partisipasi luas dan aktif, memastikan pengaruh dan kontrol berbasis luas, memfasilitasi dinamika kelompok produktif, memperluas ruang lingkup proses. Kolaborasi yang berhasil juga dapat menggunakan banyak pemimpin, secara formal dan informal, daripada mengandalkan satu pemimpin (Bradford 1998; Lasker dan Weiss 2003). Huxham dan Vangen (2000) menekankan bahwa kepemimpinan kolaboratif yang efektif cenderung membutuhkan waktu, sumber daya, dan keterampilan.

\section{The Collaborative Process}

Model proses tata kelola kolaboratif kadang-kadang menggambarkan kolaborasi sebagai pengembangan bertahap. Sebagai contoh, Susskind dan Cruikshank (1987:95) menggambarkan proses pembangunan konsensus sebagai memiliki fase pranegosiasi, fase negosiasi, dan fase implementasi. Gray (1989) mendefinisikan proses kolaborasi tiga langkah: Pengaturan masalah, Pengaturan arah, Implementasi; Edelenbos $(2005,118)$ mengidentifikasi proses tiga langkah yang mencakup persiapan, pengembangan kebijakan, dan pengambilankeputusan, dengan setiaplangkah memiliki beberapa tahap.

\section{Face to Face Dialogue}

Semua tata kelola kolaboratif dibangun berdasarkan dialog tatap muka antara para pemangku kepentingan. Sebagai proses yang berorientasi pada konsensus, 'komunikasi tebal' yang diizinkan melalui dialog langsung diperlukan bagi para pemangku kepentingan untuk mengidentifikasi peluang untuk saling menguntungkan. Namun, dialog tatap muka lebih dari sekadar media negosiasi. Ini adalah inti dari proses kolaborasi.

\section{Trust Building}

Kurangnya kepercayaan di antara para pemangku kepentingan adalah titik awal yang umum untuk pemerintahan kolaboratif (Weech-Maldonado dan Merrill 2000). Literatur sangat menyarankan bahwa proses kolaboratif tidak hanya tentang negosiasi tetapi juga tentang membangun kepercayaan di antara para pemangku kepentingan (Alexander, Comfort, dan Weiner 1998; Beierle dan Konisky 2001; Brinkerhoff 1999; Glasbergen dan Driessen 2005; Imperial 2005; Murdock, Wiessner, dan Sexton 2005; Pendek dan Musim Dingin 1999; Tett, Crowther, dan O'Hara 2003; Vangen dan Huxham 2003b). Bahkan, ketika ada prasejarah antagonisme di antara para pemangku kepentingan, kami menemukan bahwa membangun kepercayaan sering menjadi aspek yang paling menonjol dari proses kolaborasi awal dan bisa sangat sulit untuk ditumbuhkan (Murdock, Wiessner, dan Sexton 2005).

\section{Commitment to the process}

Komitmen terkait erat, tentu saja, dengan motivasi asli untuk berpartisipasi dalam tata kelola kolaboratif. Tetapi para pemangku kepentingan mungkin ingin berpartisipasi untuk memastikan perspektif mereka tidak diabaikan atau untuk mendapatkan legitimasi untuk posisi mereka atau untuk memenuhi kewajiban hukum, dll. Sebaliknya, komitmen terhadap proses berarti mengembangkan keyakinan bahwa itikad baik menawar untuk saling menguntungkan adalah cara terbaik untuk mencapai 


\section{Kebijakan: Jurnal Ilmu Administrasi \\ Volume 13, Nomor 1, Januari 2022 \\ E-ISSN: 2656-2820 \\ P-ISSN 1829-5762}

hasil kebijakan yang diinginkan (Burger et al. 2001). Keyakinan semacam itu tidak altruistik. Pengembang mungkin percaya bahwa cara terbaik untuk membangun rumahnya adalah dengan terlibat dalam upaya tawar-menawar dengan itikad baik dengan pencinta lingkungan. Namun komitmen untuk berkolaborasi masih membutuhkan perubahan psikologis yang sangat signifikan, terutama di antara mereka yang menganggap posisi mereka secara absolut (Putnam 2004; Putnam, Burgess, dan Royer 2003). Sebagai langkah pertama, perubahan semacamitu membutuhkan apa yang kadang-kadang disebut 'saling pengakuan' (Saarikoski 2000) atau 'penghargaan bersama' (Gray 1989; Plummer dan Fitzgibbon 2004).

\section{Shared Understanding}

Pada titik tertentu dalam proseskolaborasi, para pemangkukepentingan harus mengembangkan pemahaman bersama tentang apa yang dapat mereka capai bersama (Tett, Crowther, dan O'Hara 2003). Pemahaman bersama dijelaskan dalam berbagai literatur sebagai" misi bersama " (Alexander, Comfort, dan Weiner 1998; Roussos dan Fawcett 2000), " kesamaan " (Wondolleck dan Yaffee 2000), " tujuan bersama " ( Tett, Crowther, dan O'Hara 2003), " tujuan bersama " (Huxham 2003), " tujuan bersama " (Padilla dan Daigle 1998)," visi bersama " (Manring dan Pearsall 2004; Walter dan Petr 2000; Wondolleck dan Yaffee 2000), " ideologi bersama" (Waage 2001), " tujuan yang jelas " (Glasbergen dan Driessen 2005; Roberston dan Lawes 2005), " arah yang jelas dan strategis " (Margerum 2002), atau "penyelarasan nilai-nilai inti " (Heikkila dan Gerlak 2005).

\section{Intermediate Outcomes}

Sejumlah studi kasus menunjukkan bahwakolaborasi lebih mungkin terjadi ketika kemungkinan tujuan dan manfaat kolaborasi relatif konkret dan ketika "kemenangan kecil" dari kolaborasi dimungkinkan (Chrislip dan Larson 1994; Roussos dan Fawcett 2000; Warner 2006 ; WeechMaldonado dan Merrill 2000). Meskipun hasil-hasil antara ini dapat mewakili hasil nyata dalam diri mereka sendiri, kami mewakili mereka di sini sebagai hasil proses kritis yang penting untuk membangun momentum yang dapat mengarah pada kolaborasi yang sukses. Kemenangan kecil ini dapat memberi umpan balik ke dalam proses kolaborasi, mendorong siklus kebajikan membangun kepercayaan dan komitmen (Rogers et al. 1993; Vangen dan Huxham 2003b)

\section{SIMPULAN}

Partisipasi dengan kesadaran sendiri individu dan tersistem pada pola induk aturan yang di buat di pasar tradiosional dapat dikembangkan dengan sanksi yang tegas. Menjaga kebersihan lingkungan pasar.Pasar-pasar tradisional di kota Bandung telah dilengkapi dengan tempat pembuangan sampah sementara (TPS) atau bak sampah sebelum di angkut ke tempat pembuangan akhir(TPA) oleh petugas kebersihan. Namun, adanya tempat sampah tersebut cenderung tidak dimanfaatkan dengan baik oleh paraterkait dengankehidupan di pasartradisional. Hasil observasi dan pengamatan di lapangan menunjukkan bahwa sampah yang berada di pasar tersebut belum dikelola dengan baik. Hal ini ditunjukkan dari penumpukan sampah dan daya tampung (TPS) yang kurang memadai di pasar sehingga sampah tercecer dimana-mana. Di sisi lain pola perilaku pengguna pasar yang belum dan cenderung tidak memiliki kesadaran untuk menjaga kebersihan besrama dan partisipasi dalam pengelolaan sampah masih kurang dan terabaikan. Hal ini menyebabkan pasar menjadi tempat yang kotor, bau dan kumuh. 


\section{Kebijakan: Jurnal Ilmu Administrasi \\ Volume 13, Nomor 1, Januari 2022 \\ E-ISSN: 2656-2820 \\ P-ISSN 1829-5762}

Literaturnya jelas bahwa kondisi yang ada pada awal kolaborasi dapat memfasilitasi atau menghambat kerja sama di antara para pemangku kepentingan dan antara lembaga dan pemangku kepentingan. Bayangkan dua titik awal yang sangat berbeda. Dalam satu, para pemangku kepentingan memiliki sejarah pembagian pahit atas beberapa masalah lokal yang dibebankan secara emosional dan telah menganggap satu sama lain sebagai musuh yang tidak bermoral. Dalamkedua kasusitu, kolaborasi mungkin sulit, tetapi kasus pertama harus mengatasi masalah ketidakpercayaan, rasa tidak hormat, dan pertentangan langsung. Kami mempersempit kondisi awal kritis menjadi tiga variabel besar: ketidakseimbangan antara sumber daya atau kekuatan pemangku kepentingan yang berbeda, insentif yang harus dikolaborasikan oleh pemangku kepentingan, dan sejarah konflik atau kerja sama sebelumnya di antara para pemangku kepentingan.

1. Karakteristik sampah di Kota Bandung terdiri dari sampah Organik (Sisa-sisamakanan, sayursayuran, buah-buahan) dan sampah Anorganik (plastik, alumunium, logam). Dari hasil penelitian dapat dikemukakan bahwa bahwa secara umum karakteristik sampah masih dominan sampah organik yang sebetulnya sangat mudah di oleh untuk kepentingan pembangunan lingkungan.

2. Faktor-faktor yang mempengaruhi partisipasi public dalam pengelolaan sampah di Kota Bandung dengan model sister city menunjukan bahwa faktor internal (pendidikan, pendapatan, kepedulian terhadap sampah, pengetahuan tentang sampah) sementara pengetahuan tentang sampah pada aspek (Jenis sampah) tidak mempengaruhi tingkat partisipasi public, demikian juga faktor eksternal meliputi (peraturan, bimbingan dan penyuluhan, dan fasilitas teknologi).

3. Kondisi lingkungan(kondisi drainase) tidakmempengaruhi tingkat partisipasi public. Berjalan Ketika curah hujan tinggi dan banjir yang setiap tahun teralami. Memang perlunya meningkatkan sumber daya.

\section{DAFTAR PUSTAKA}

Abdelhadi, A. W., H. S. Adam, Mohamed A. Hassan, and Takeshi Hata. 2004. Participatory management: Would it be a turning point in the history of the Gezira Scheme? Irrigation and Drainage. 53:429-36.

Alexander, Jeffery A., Maureen E. Comfort, Bryan J. Weiner. 1998. Governance in public-private community health partnerships: A survey of the Community Care Network: SM demonstration sites. Nonprofit Management \& Leadership. 8:231-332.

Andranovich, Greg. 1995. Achieving consensus in public decision making: Applying interest based problem-solving to the challenges of intergovernmental collaboration. Journal of Applied Behavioral Research 31:429-45.

Ansell, Christopher K. 2003. Community embeddedness and collaborative governance in the San Franciscobay area environmental movement. In Social movements and networks: Relational approaches to collective action, ed. Mario Diani and Doug McAdam, 123-44. Oxford: Oxford Univ. Press.

Beierle, Thomas C. 2000. The quality of stakeholder-based decisions: Lessons from the case study record. Discussion Paper 00-56, Resources for the Future.

Beierle, Thomas C., and David Konisky. 2001. What are we gaining from stakeholder involvement? Observations from environmental planning in the Great Lakes. Environment and Planning C: Government and Policy 19:515-27. 


\section{Kebijakan: Jurnal Ilmu Administrasi \\ Volume 13, Nomor 1, Januari 2022 \\ E-ISSN: 2656-2820 \\ P-ISSN 1829-5762}

Beierle, Thomas C., and Rebecca J. Long. 1999. Chilling collaboration: The Federal Advisory Committee Act and stakeholder involvement in environmental decisionmaking. Environmental Law Reporter 29:10399.

Bentrup, Gary. 2001. Evaluation of a collaborative model: A case study of analysis of watershed planning in the Intermountain West. Environmental Management 27:739-48.

Blatner, Keith, Matthew Carroll, Steven Daniels, and Greg Walker. 2001. Evaluating the application of collaborative learning to the Wenatchee fire recovery planning effort. Environmental Impact Assessment Review 21:241-70.

Booher, DavidE., and Judith Innes. 2002. Network power in collaborative planning. Journal of Planning Education and Research 21:221-36.

Borrini-Feyerabend, Grazia. 1996. Collaborative management of protected areas: Tailoring the approach to the context. Gland, Switzerland: IUCN-The World Conservation Union.

Bouwen, Rene, and Tharsi Taillieu. 2004. Multi-party collaboration as social learning for interdependence: Developing relational knowing for sustainable natural resource management. Journal of Community \& Applied Social Psychology 14:137-53.

Bradford, Neil. 1998. Prospects for associative governance: Lessonsfrom Ontario, Canada. Politics \& Society 26:539-73.

Brinkerhoff, Derick W. 1999. Exploring state-civil society collaboration: Policy partnershipsin developing countries. Nonprofit and Voluntary Sector Quarterly 28 (Suppl. 1):59-86.

Brown, A. J. 2002. Collaborative governance versus constitutional politics: Decision rules for sustainability from Australia's South East Queensland forest agreement. Environmental Science and Policy 5:19-32.

Bryson, John M., and Barbara C. Crosby. 1992. Leadership for the common good. San Francisco, CA:Jossey-Bass.

Bryson, John M., Gary Cunningham, and Karen Lokkesmoe. 2002. What to do when stakeholders matter: The case of problem formulation for the African American Men Project of Hennepin County, Minnesota. Public Administration Review 62:568-84.

Buanes, Arild, Svein Jentoft, Geir Runar Karlsen, Anita Maurstad, and Siri Søreng. 2004. In whose interest? An exploratory analysis of stakeholders in Norwegian coastal zone planning. Ocean \& Coastal Management 47:207-23.

Burger, Joanna, Michael Gochfeld, Charles W. Powers, Lynn Waishwell, Camilla Warren, and

Bernard D. Goldstein. 2001. Science, policy, stakeholders, and fish consumption advisories: Developing a fish fact sheet for Savannah River. Environmental Management 27: 501-14.

Busenberg, George. 1999. Collaborative and adversarial analysis in environmental policy. Policy Sciences 32:1-11.

Carter, Jane, Brieke Steenhof, Esther Haldimann, and Nurlan Akenshaev. 2003. Collaborative forest management in Kyrgyzstan: Moving from top-down to bottom-up decisionmaking. Gatekeeper Series No. 108, International Institute for Environment and Development.

Chrislip, David, and Carl E. Larson. 1994. Collaborative leadership: How citizens and civic leaders can make a difference. San Francisco, CA: Jossey-Bass.

Coggins, Goerge C. 1999. Regulating federal natural resources: A summary case against devolved collaboration. Ecology Law Quarterly 25:602.

Coglianese, Cary. 1997. Assessing consensus: The promise and the performance of negotiated rulemaking. Duke Law Journal 46:1255. 


\section{Kebijakan: Jurnal Ilmu Administrasi \\ Volume 13, Nomor 1, Januari 2022 \\ E-ISSN: 2656-2820 \\ P-ISSN 1829-5762}

Coglianese, Cary, and Laurie K. Allen. 2003. Building sector-based consensus: A review of the EPA's Common Sense Initiative. Working Paper RWPO3, JFK School of Government.

Conley, Alexander, and Margaret A. Moote. 2003. Evaluating collaborative natural resource management. Society and Natural Resources 16:371-86.

Dunn, William N. 1999. Pengantar Analisis Kebijakan Publik. (Edisi Bahasa Indonesia). Yogyakarta: Gajah Mada University Press.

Dwijowijoto, Riant Nugroho. 2003. Kebijakan Publik: Formulasi, Implementasi, dan Evaluasi. Jakarta: PT. Gramedia.

Landry, Charles. 2008. Creative city: a toolkit for urban innovation. London: Earthscan Moleong, Lexy J., 2004, Metodologi Penelitian Kualitatif, Bandung, Remaja Rosda Karya.

Nugroho, Riant, 2014, Kebijakan Publik di Negara-negara Berkembang, Yogyakarta, Pustaka Pelajar. Nugroho, Riant, 2012, Public Policy, Jakarta, PT. Elex Media Komputindo.

Sugiyono, 2011, Metode Penelitian Kombinasi (Mixed Methods), Alfabeta, Bandung.

Jurnal, Sister City,Mukti 2013

\section{Peraturan Perundang-undangan:}

Undang-Undang Dasar Republik Indonesia Tahun 1945.

Undang-Undang Nomor 32 tahun 2009 tentang Perlindungan dan pengelolaan lingkungan hidup permendagri nomor 1 tahun 1992 tentang kerjasama sister city

peraturan menteri dalam negeri nomor 3 tahun 2008 tentang pedoman pelaksanaan kerjasama pemerintah daerah dengan pihak luar negeri

UU-18/2008 tentang Pengelolaan Sampah

\section{Internet:}

(http://penataanruang.pu.go.id).

http://mongabay.co.id

http://pdkebersihan.bandung.go.id

http://bdg.ksln.co.id

http://bplhkotabandung.com 